\title{
Udder conformation and housing system as related to somatic cell count in cow's milk
}

\author{
P. Wójcik ${ }^{1}$ \\ National Research Institute of Animal Production \\ 32-083 Balice, Poland
}

(Received 19 January 2007; revised version 3 April 2007; accepted 2 May 2007)

\begin{abstract}
A total of 3592 cows, which first calved in 2003 and completed their 305-day lactation, were kept in a tied (2580 animals) or loose housing system (1012 animals). All animals were assessed for udder conformation between 15 and 180 days after calving. Control milkings were performed once a month for 10 consecutive months to determine somatic cell count (SCC) in milk. The SCC in milk was found to vary according to the housing system and was much lower in loose-housed cows. There were highly significant relationships between the conformation of different parts of the udder and SCC in milk samples. Milk of cows with fore udder attachment, given a score of over 5 points in both housing systems, was characterized by the lowest SCC. For rear udder attachment, similar or lower SCC were observed for scores of 4-6 points than for scores of 2-3 points, when SCC was the highest. Animals scoring over 5 points for median suspensory ligament and udder placement were characterized by the lowest SCC in milk. SCC in milk decreased as udder attachment became stronger and higher, regardless of the animal housing system. Cows with closely spaced rear teats and centrally located front teats showed low variation in milk SCC. In the loose system, teat length did not significantly affect SCC in the analysed milk samples, but a tendency towards this occurred in the tied housing system.
\end{abstract}

KEY WORDS: dairy cattle, udder conformation, housing systems, somatic cells

\section{INTRODUCTION}

Evaluation of udder health is based on the determination of somatic cell count (SCC) in milk (Ward and Schultz, 1972; Akers and Thompson, 1987; Fetrow et al., 1988). The number of somatic cells per $\mathrm{ml}$ of milk provides information on

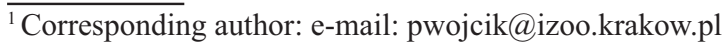


subclinical or clinical forms of mastitis and on technological suitability of milk. Considering that udder disorders are responsible for over of 30\% disease-related losses and clinical signs of mastitis occur at least once per lactation in $40 \%$ of cows (Sawa and Piwczyński, 2003), it is necessary to develop selection methods enabling the elimination of such unfavourable phenomena in the herd. These can be limited by using a conformation evaluation system with a scale of 1-9 points, which describes the animal's body conformation and defects (Nash et al., 2000). The results obtained can serve as a basis for selection for improved conformation of some parts of the body and thus improved health and productivity of animals (Monardes et al., 1990; Rogers et al., 1991). Udder scoring is mainly aimed at improving udder conformation to make mechanical milking more efficient and to reduce the incidence of udder infections and injuries, thus considerably improving the hygienic parameters of the obtained milk. In Poland, there are still no indices used for somatic cells and conformation traits.

The aim of the present study was to determine the relationship between udder conformation and SCC in milk with regard to the housing system of cows, and thus to show the potential for increasing the use of the conformation scoring system for improving udder health and milk quality.

\section{MATERIAL AND METHODS-}

Polish Holstein-Friesian (PHF) first calves of Black-and-White variety, evaluated in 2003, were assigned to two groups: the tied housing system (2580 animals in 398 herds) or the loose housing system with cubicles (1012 animals in 158 herds). The conformation of animals was scored on a scale of 1 to 9 between 15 and 180 days after first calving based on KCHZ regulations (1996). Ten samples of milk were taken during 10 consecutive control milkings to analyse SCC per $\mathrm{ml}$ of milk drawn. Cows were characterized by lactations longer than 305 days and were not treated pharmacologically. Mean udder conformation scores and SCC levels in the milk of cows from each group were analysed. Numerical data were subjected to 3-way variance analysis based on the SAS statistical package using the following model:

$$
\mathrm{Y}_{\mathrm{ijkl}}=\mu+\mathrm{A}_{\mathrm{i}}+\mathrm{B}_{\mathrm{j}}+\mathrm{C}_{\mathrm{k}}+\mathrm{e}_{\mathrm{ijk} \mathrm{k}}
$$

where: $\mathrm{Y}_{\mathrm{ijkl}}-$ value of trait

$\mu$ - mean

$A_{i} \quad$ - fixed effect of herd-year-season (HYS)

$B_{j} \quad-$ effect of $j$-th udder conformation trait

$\mathrm{C}_{\mathrm{k}}$ - effect of $\mathrm{k}$-th sample (1-10)

$\mathrm{e}_{\mathrm{ijk} \mathrm{l}}-$ random error 
Log transformation was used to obtain a normal distribution of SCC. To determine the relationship between housing system and SCC, two-way variance analysis was performed for the housing system and season of evaluation, using the date of sampling as a concomitant variable (Table 1).

\section{RESULTS}

It was found that SCC levels in loose-housed cows were much lower $(\mathrm{P}<0.01)$ than in cows housed in the tied system (Table 1), with the greatest

Table 1. Somatic cell count in the milk of cows in 1st lactation according to housing system

\begin{tabular}{|c|c|c|c|c|c|c|c|c|c|c|}
\hline \multirow{2}{*}{$\begin{array}{l}\text { Housing } \\
\text { system }\end{array}$} & \multicolumn{10}{|c|}{ Somatic cell count by month after day of calving, thous./ml } \\
\hline & 1 & 2 & 3 & 4 & 5 & 6 & 7 & 8 & 9 & 10 \\
\hline $\mathrm{x}$ & $702.9^{\mathrm{a}}$ & $522.4^{\mathrm{A}}$ & $578.1^{\mathrm{A}}$ & $562.1^{\mathrm{A}}$ & $586.5^{\mathrm{A}}$ & $684.0^{\mathrm{A}}$ & $663.4^{\mathrm{A}}$ & $621.4^{\mathrm{A}}$ & $587.1^{\mathrm{A}}$ & $645.2^{\mathrm{A}}$ \\
\hline Tied SD & 1677.1 & 1320.0 & 1520.1 & 1392.0 & 1530.3 & 1856.7 & 1762.4 & 1620.9 & 1352.8 & 1706.0 \\
\hline $\mathrm{x}$ & $648.2^{\mathrm{a}}$ & $447.9^{\mathrm{A}}$ & $401.1^{\mathrm{A}}$ & $494.6^{\mathrm{A}}$ & $445.0^{\mathrm{A}}$ & $442.1^{\mathrm{A}}$ & $428.4^{\mathrm{A}}$ & $469.7^{\mathrm{A}}$ & $512.5^{\mathrm{A}}$ & $458.6^{\mathrm{A}}$ \\
\hline Loose SD & 1531.6 & 1210.1 & 981.1 & 1379.5 & 1268.8 & 1032.9 & 1041.3 & 1275.5 & 1273.8 & 956.6 \\
\hline SE & 24.81 & 19.58 & 20.52 & 21.42 & 22.25 & 25.02 & 24.27 & 24.46 & 24.35 & 20.26 \\
\hline $\mathrm{P}$ & 0.0362 & 0.0011 & 0.0001 & 0.0001 & 0.00001 & 0.0001 & 0.0001 & 0.0001 & 0.0001 & 0.0011 \\
\hline
\end{tabular}

within column: ${ }^{\mathrm{A}}-\mathrm{P}<0.01,{ }^{\mathrm{a}}-\mathrm{P}<0.05$

differences found in samples 6 and 7 (over 200000 cells). In both systems, the highest SCC level was found in the first sample (648 000-702 000), while in the other samples these differences ranged from 68000 to 187000 cells. Within each system, SCC remained similar throughout the study period. Highly significant relationships were found between the conformation score of different parts of the udder and SCC.

In both housing systems, the animals scoring over 5 points for fore udder attachment (Figure 1, 1A) were characterized by the lowest SCC level (299 000753000 cells), while in the cows scoring 1-4 points, SCC reached 1263000. Differences between the systems were statistically significant.

For rear udder attachment (Figure 2, 2A), the SCC level tended to even out for scores of 5-6 points. For scores of 2-3 points for rear udder attachment, mean SCC levels in both systems ranged from 984000 to 1145000 . When the score exceeded 7 points, SCC increased to as much as 1329000 in the tied housing system and decreased to 159000 in the loose housing system $(\mathrm{P}<0.05)$.

In both systems, the animals scoring over 5 points for median suspensory ligament (Figure 3, 3A) were characterized by the lowest $(\mathrm{P}<0.05) \mathrm{SCC}$, although cows in tie-up stalls had higher SCC levels. There was large variation in milk SCC in cows scoring 1-3 points (141 000-1 392000 cells) in both systems. When the score was 4 points, SCC became more uniform. 


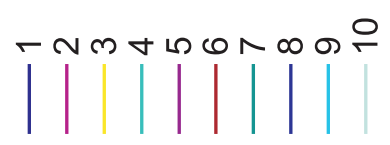

$\infty$

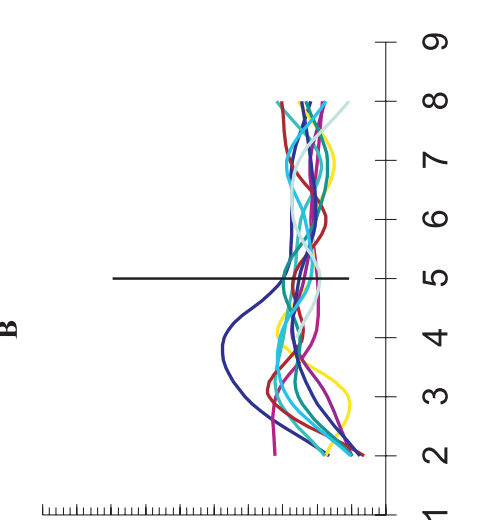

৪৪৪৪৪৪৪৪৪৪০ ํㅣㄴㄷㄴㅇㅔ

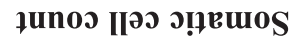

- NM
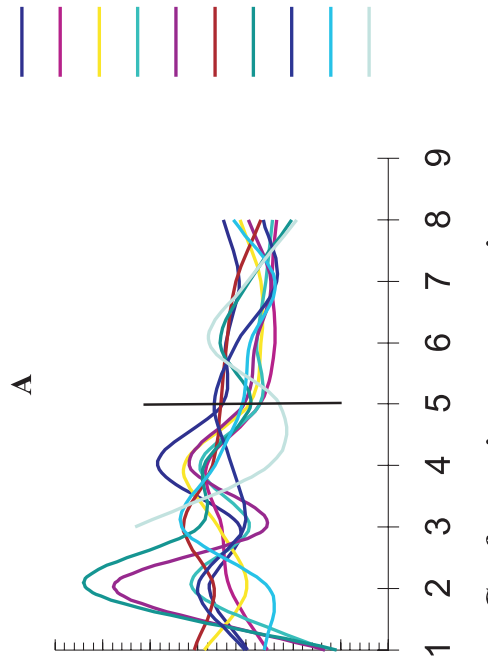

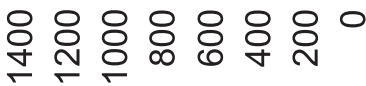

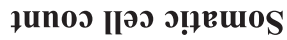

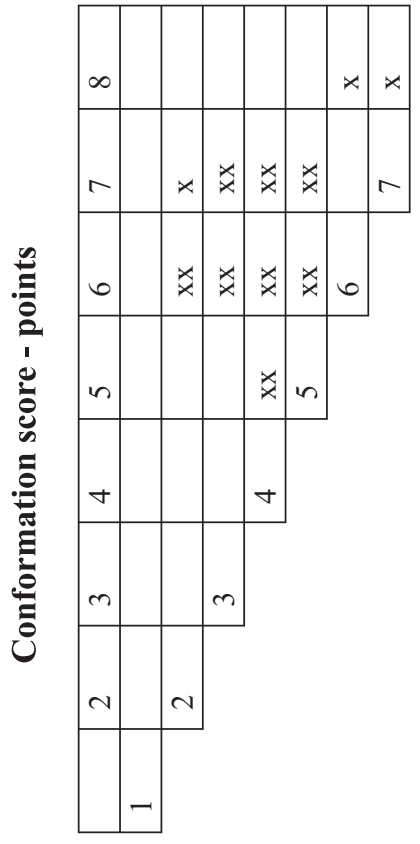

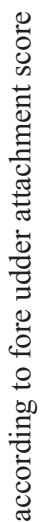

悬

$\infty \times \ddot{x} \times x$

0
0
0
0
1
$x$
$\dot{0}$
$\dot{0}$
0
0

击 焉

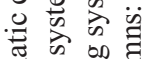

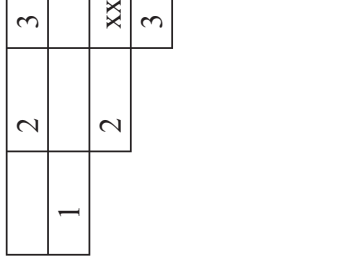

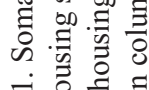
흥 강

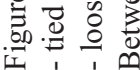




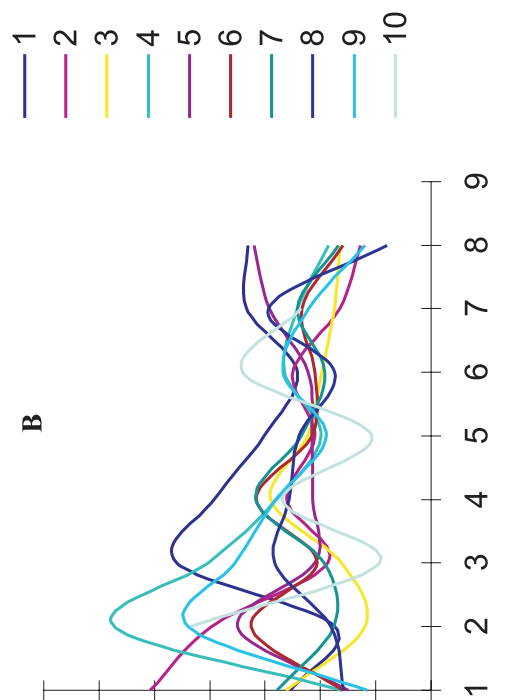

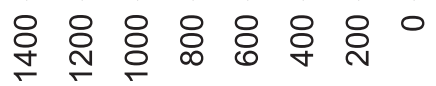

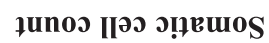

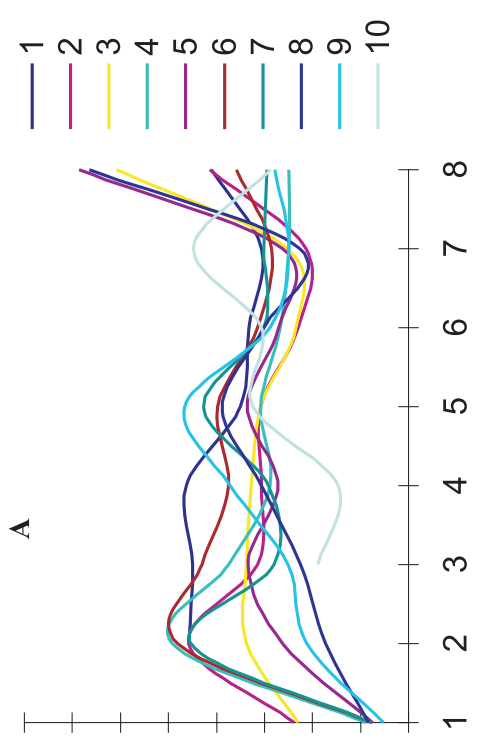

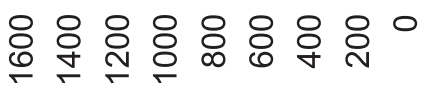
ұUnoว IIวว ว!ฺ

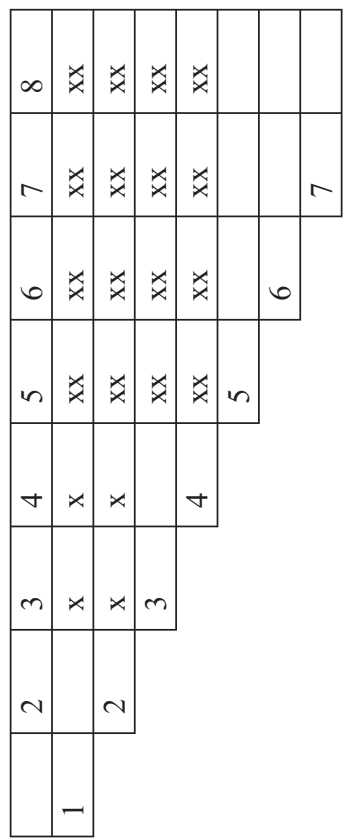

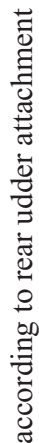

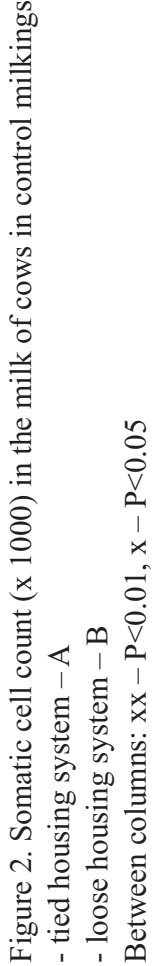


WÓJCIK P.

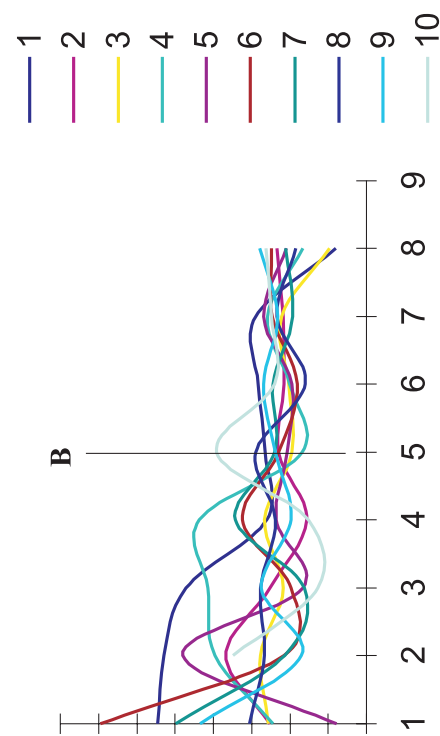

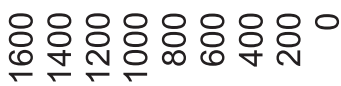

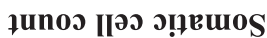

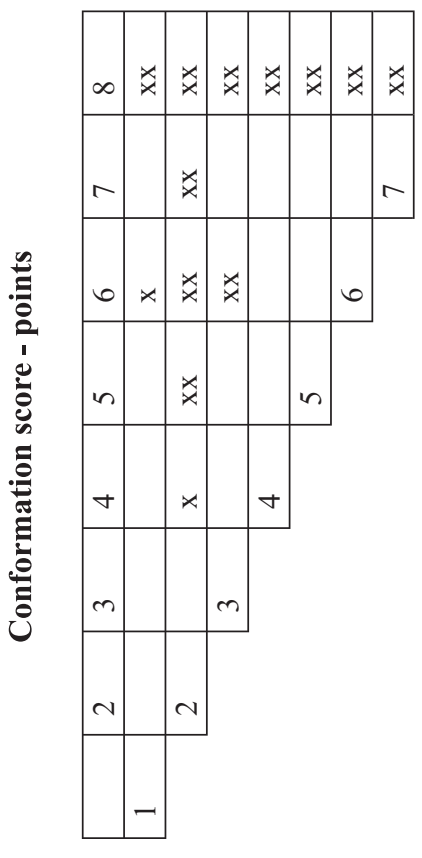

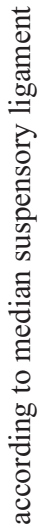

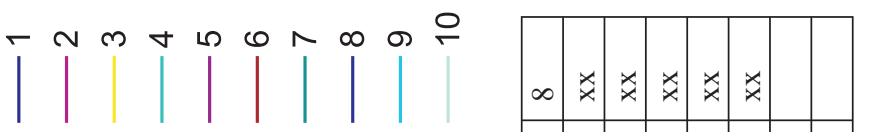

奇 잉

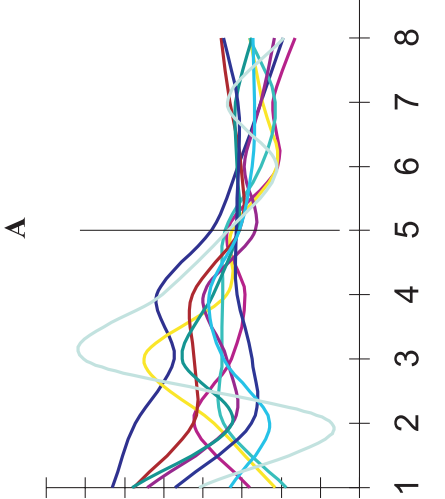

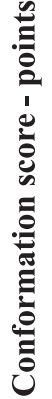

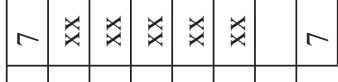

$0 \underset{x}{x} \underset{x}{x} \underset{x}{x} \underset{x}{x} \underset{x}{x}$

$\operatorname{nn} x \times x \times x$

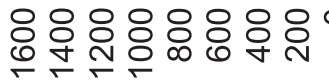

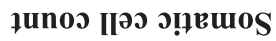

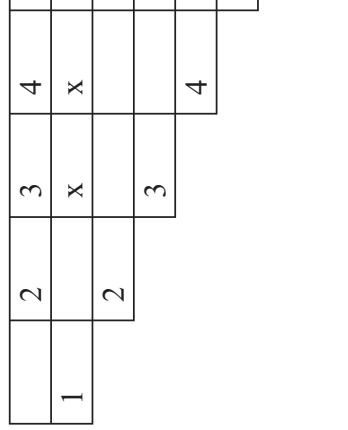

ま

0
0
0
0
1
0
0
0
0
1
$x$
0
0
0
0
0
0
0
0
0
0
0 
In both housing systems, SCC in the analysed milk samples decreased with increasing udder height (Table 4, 4A). The lowest variation in SCC (87 000 975000 ) was found for udder placement scores of 5 points and over. In animals with lower scores, SCC varied considerably from sample to sample (107 000$1826000)$. Small variation in milk SCC was observed for rear teats placement scores exceeding 4 points (Figure 5, 5A). Cows with scores of 1-3 points for all 10 milk sampling periods were characterized by the highest SCC that reached 2065000 per ml of milk. For scores of 7-8 points, SCC ranged from 258000 to 811 000 . SCC showed greater variation in the loose system than in the tied system.

For central placement of fore teats and scores of 4-5 points, SCC levels in both systems were the lowest in particular samples of milk (Figure 6, 6A). Mean SCC for teat placement scores of 3-5 points ranged from 336000 to 697000 . When teats were too close together (6-8 points) or too far apart (1-2 points), this resulted in considerable variation with SCC ranging from 1641000 to 135000 . The evaluation of teat length showed that animals with scores over 4 points had a more stable SCC level than cows with scores of 1-3 points (Figure 7, 7A). However, these relationships were only shown for the tied housing system. Teat length was unrelated to SCC in the loose housing system.

\section{DISCUSSION}

The obtained results clearly show that compared with the tied housing system, loose housing of cows has a beneficial effect on reducing milk SCC. The high level of SCC in the first milk sample (not earlier than 6 days after calving) was similar to that obtained by Rajala-Schultz et al. (1999). In the next samples, in both systems the level of SCC in milk remained similar up to and including the 10th sample. Bogucki and Sawa (2004) showed in a study analysing 3830 milk samples that stage of lactation is the smallest diversifying factor in the results of microbiological tests. However, other authors noted the highest SCC level in the 4th month of lactation and many authors conclude that milk SCC is clearly dependent on the period of lactation (Jones et al., 1998; Sawa and Piwczyński, 2002). Fore udder attachment scored as 5 points proved the most beneficial in terms of SCC in milk. No clear relationship was found between rear udder attachment and SCC in milk, although SCC levels were clearly evened out for scores of 5-6 points. Also Krupp and Boichard (1999) showed low coefficients of correlation between rear udder attachment and SCC ( $\mathrm{r}=0.13)$. Rear udder attachment is less related to milk SCC but is primarily useful in genetic selection for placement of udder in terms of easy calving. Kozaniecki et al. (1985) showed that mastitis was more frequent in cows with a rounded udder (11.2\% of quarters) than in cows with a trough-shaped udder $(7.3 \%)$. The evaluation of fore and rear attachment also determines udder 
WÓJCIK P.
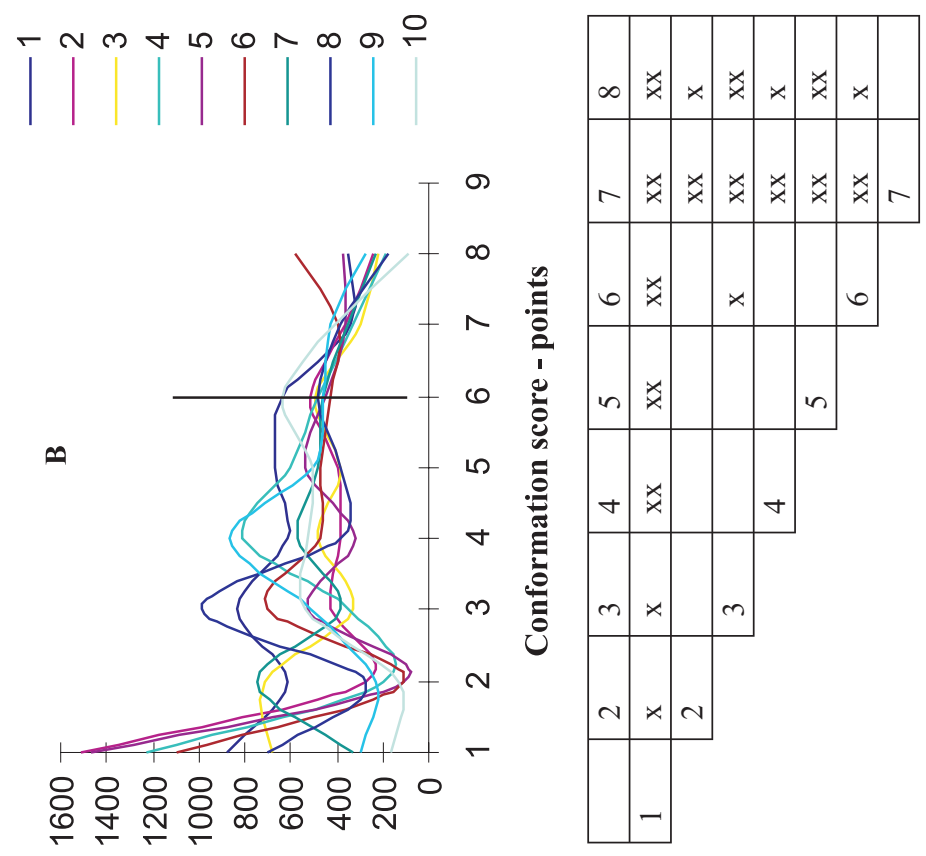

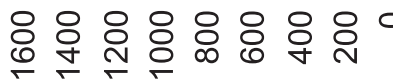

funoว IIวว ग!̣
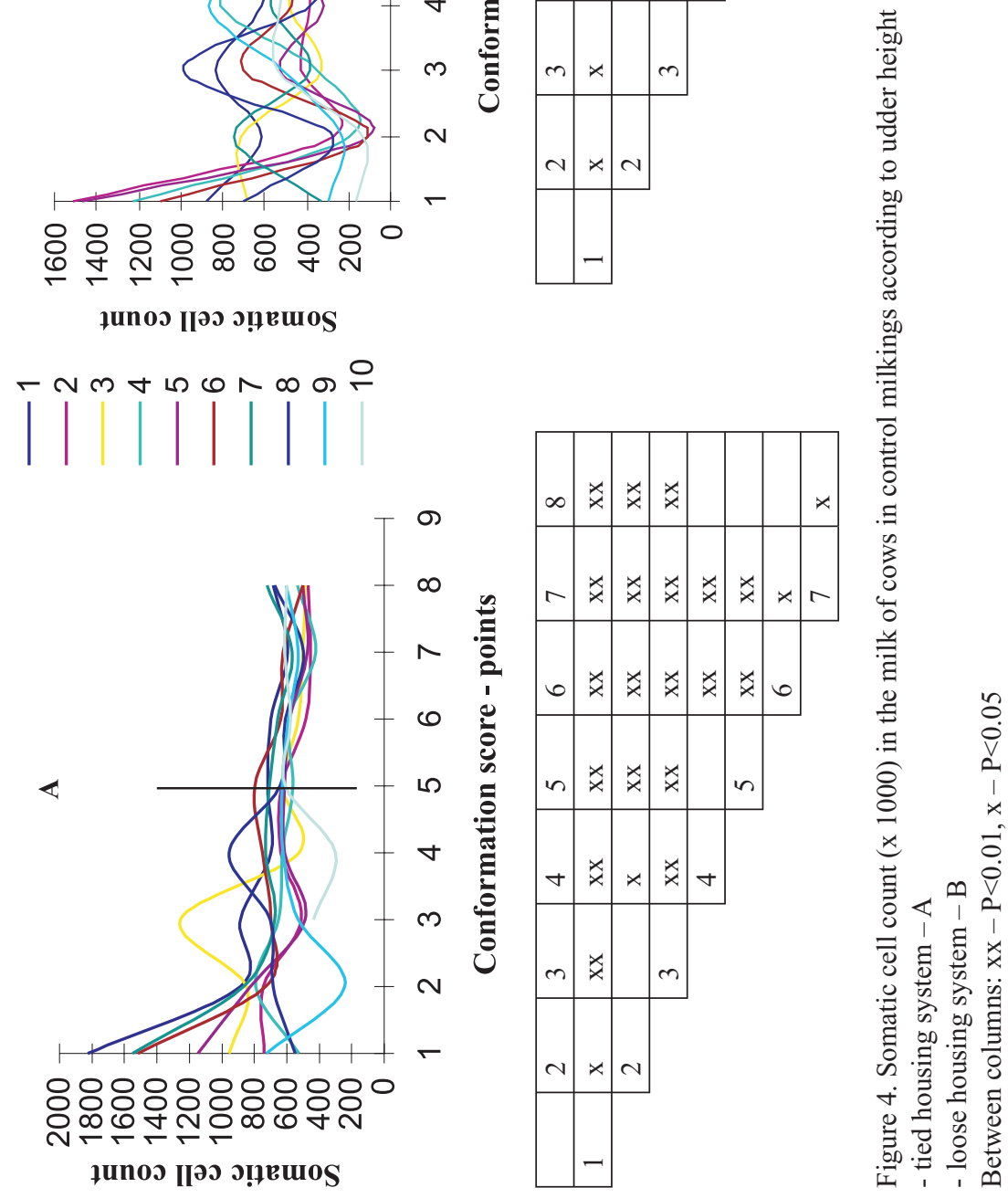

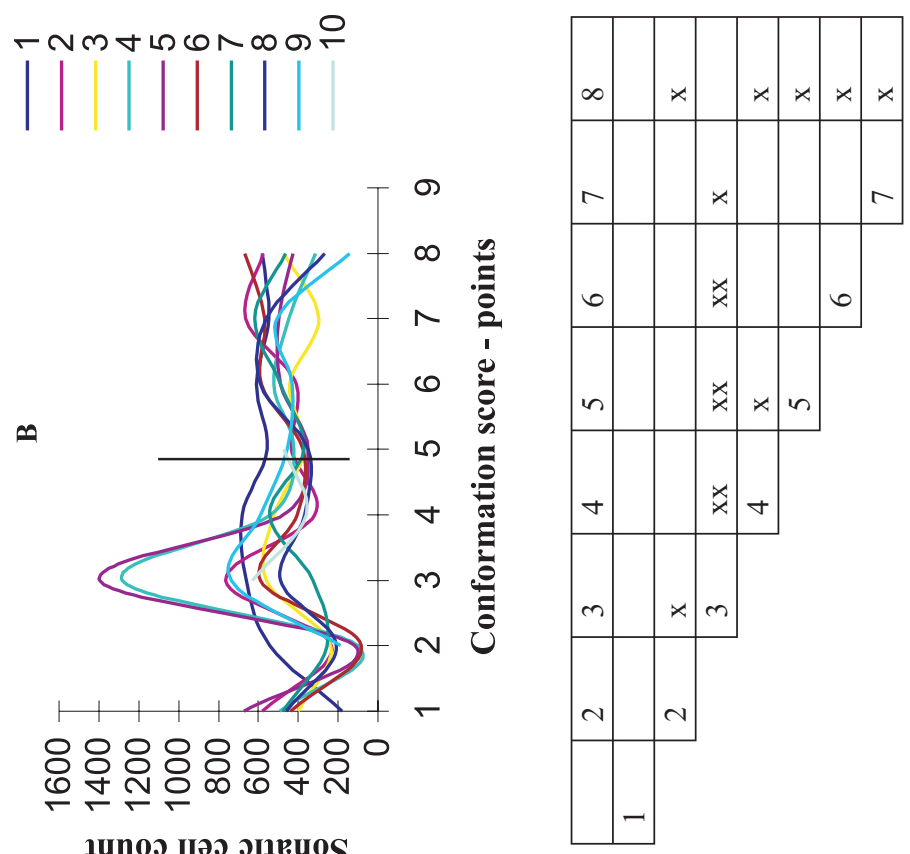

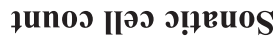
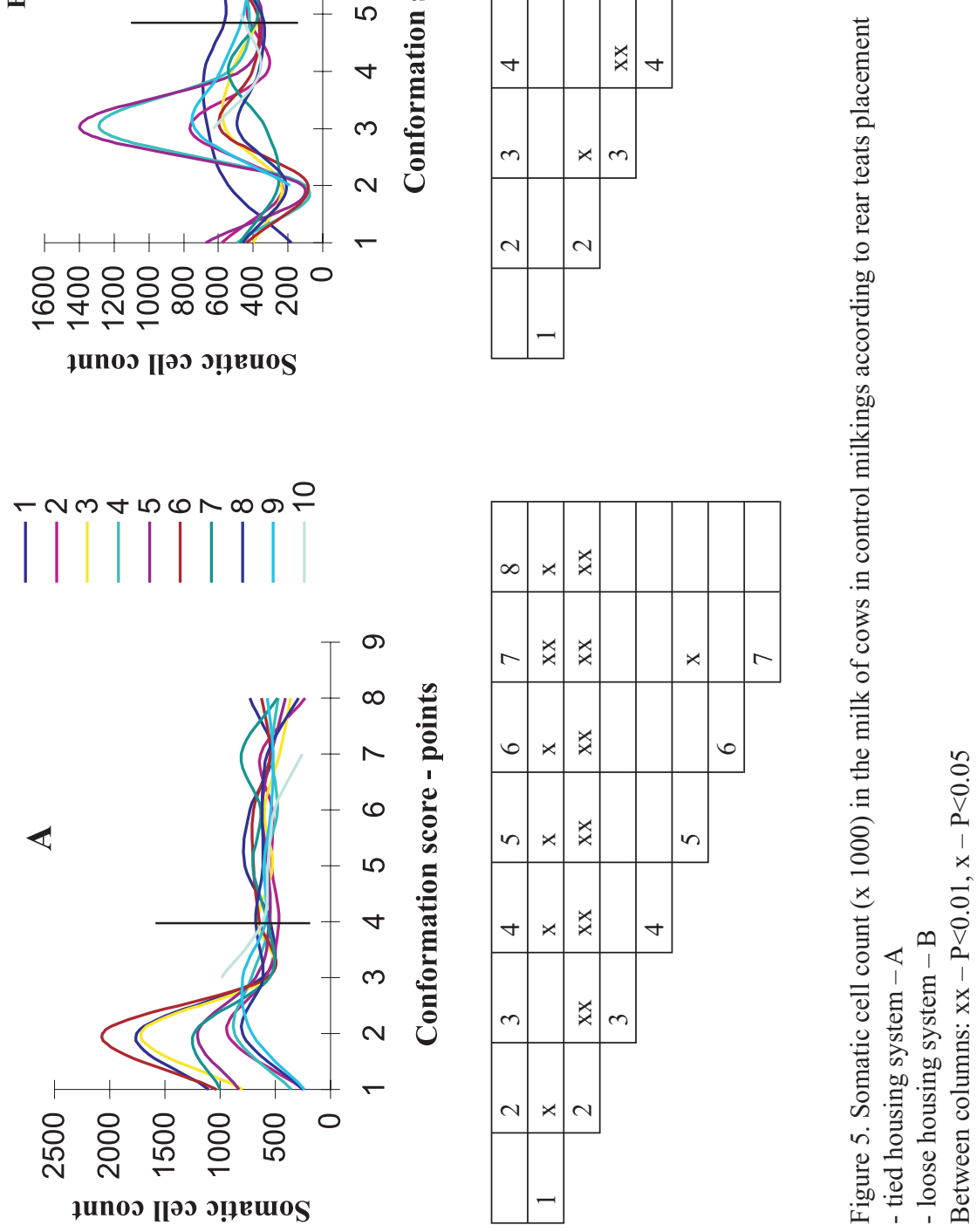


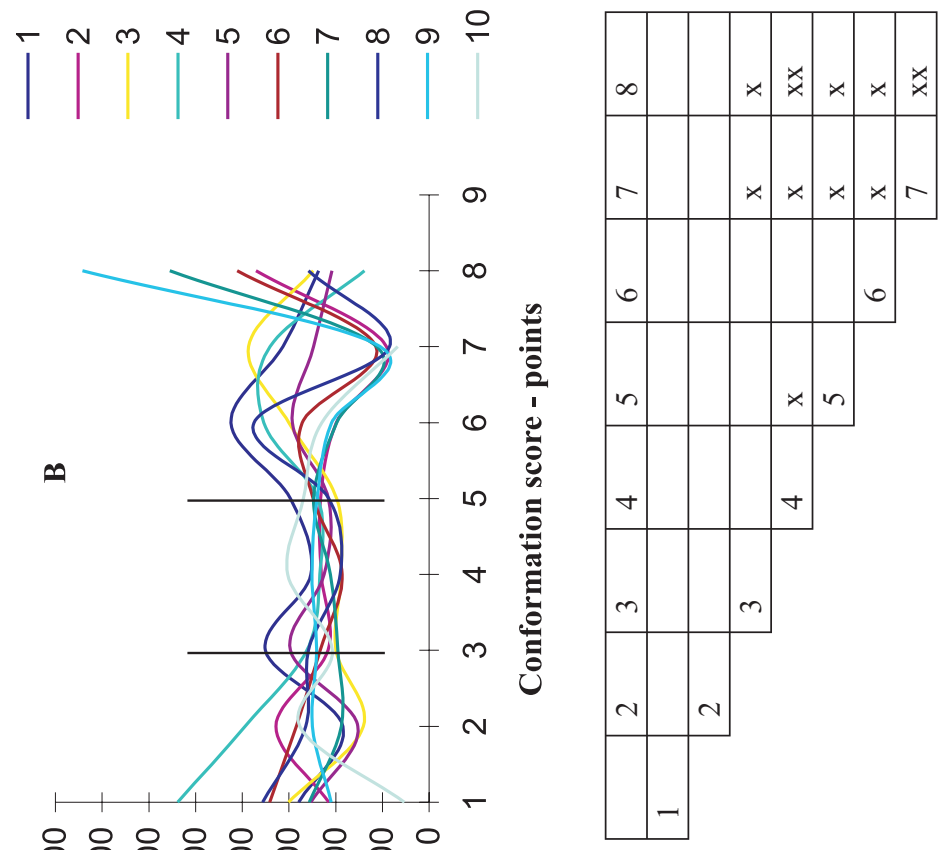

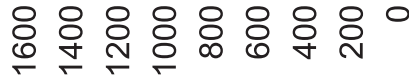

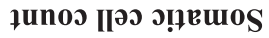

- NmtLCNOR
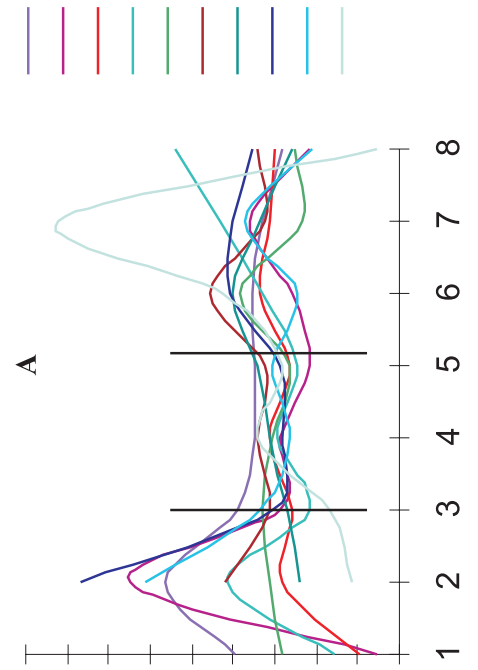

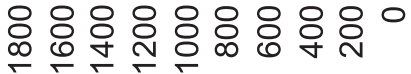
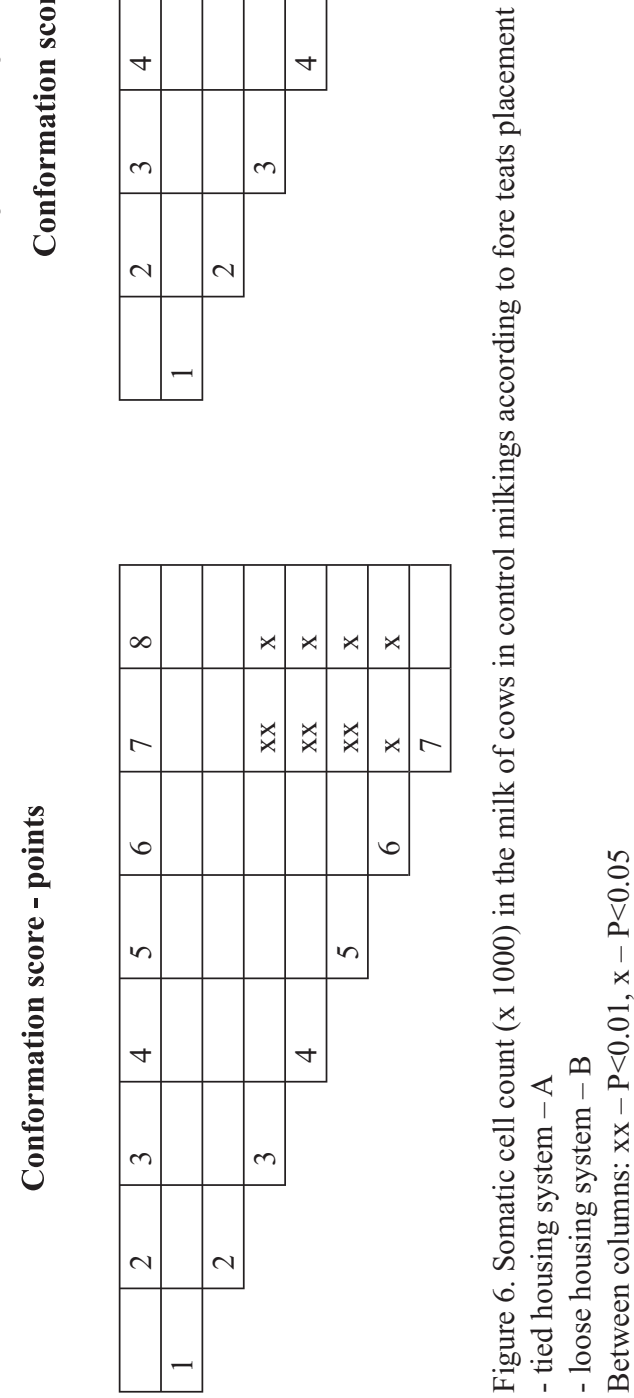

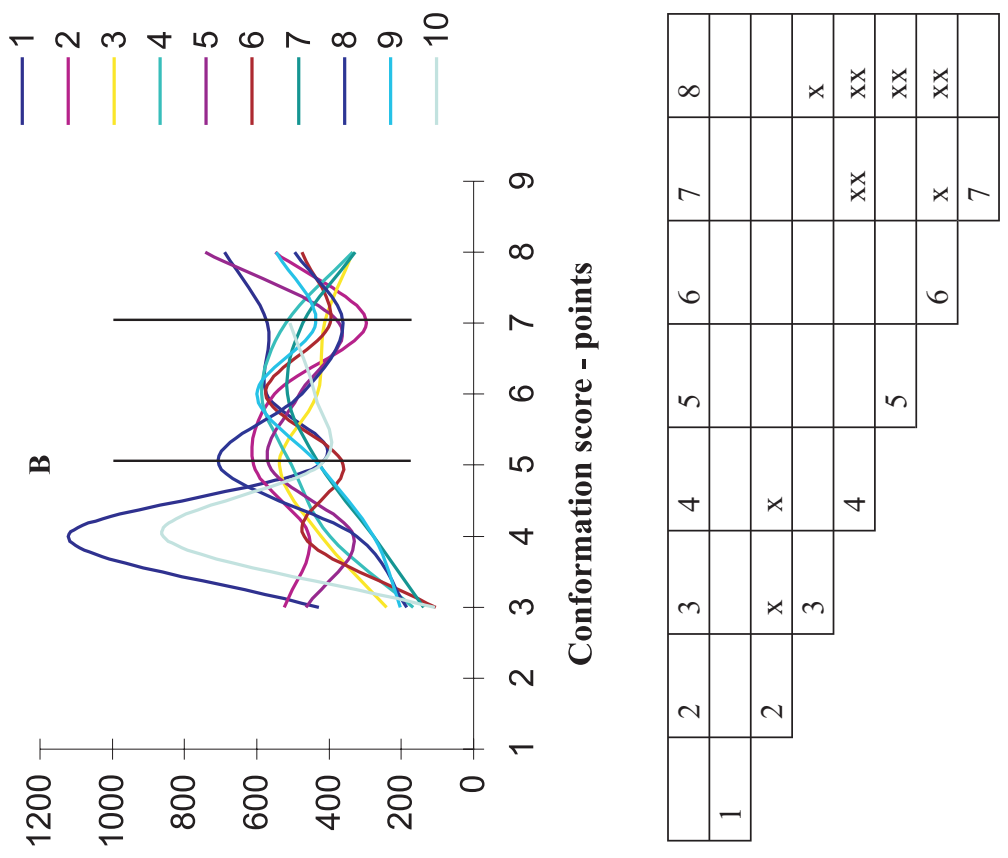

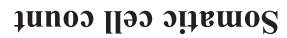
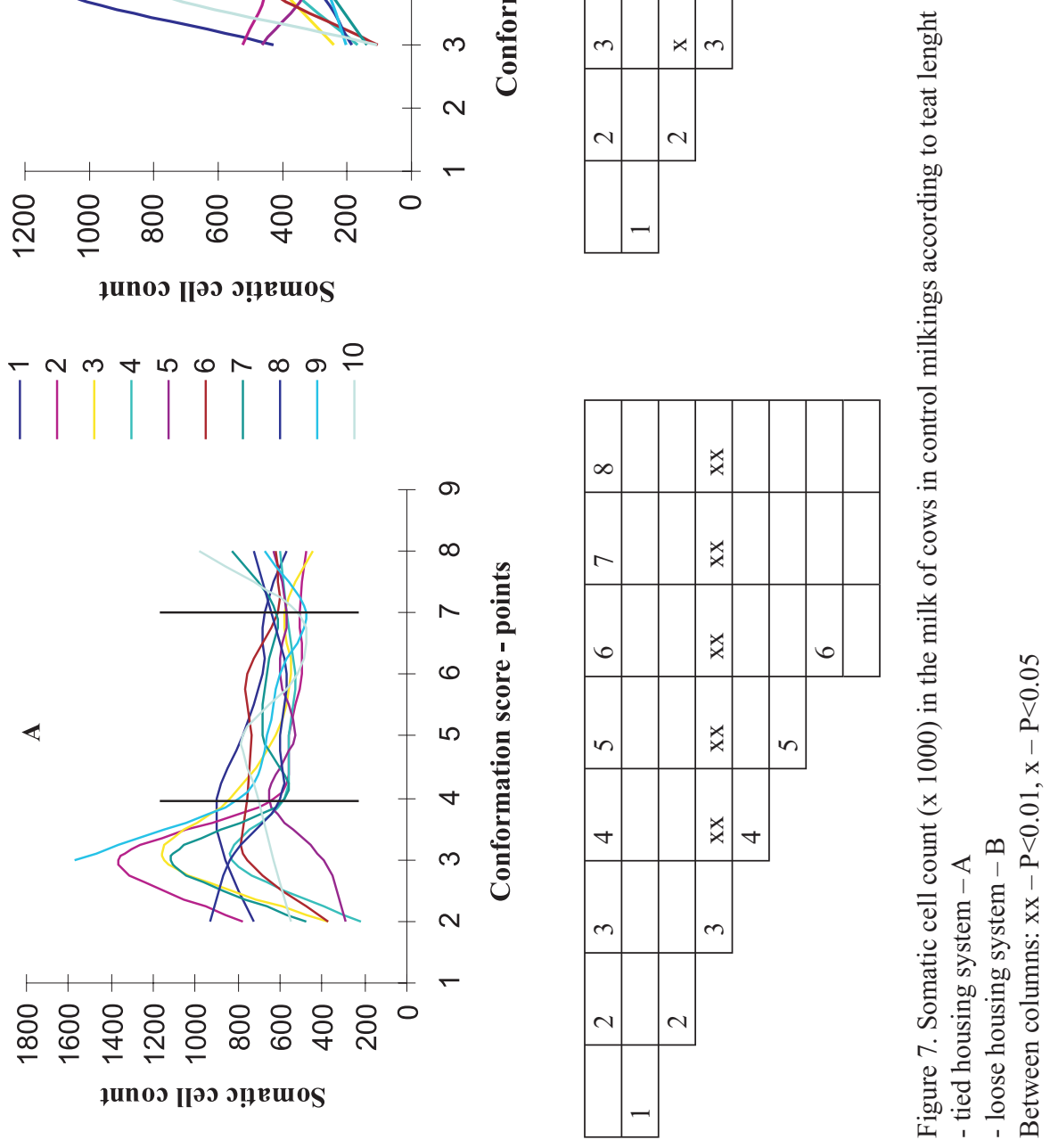
shape in the analysed cows. Krupp and Boichard (1999) demonstrated that udder traits such as depth, balance or fore extension are negatively correlated with SCC $(\mathrm{r}=-0.29$ to -0.40$)$, which means that with increasing scores for the analysed traits (i.e. increasingly normal conformation) the SCC in milk decreases. The function of the median suspensory ligament is to keep the udder at an appropriate height during the period of milk utilization and thus it determines udder conformation. A strong ligament that is clearly visible along its entire length is given a score of 9 points, and a weak and poorly visible ligament is given a score of 1 point. Giving a cow a score above 5 points not only defines the ligament's position but also indicates a reduction in milk SCC. This suggests that conformation traits can be used to a greater extent in selection of mastitis-resistant animals. Zhang et al. (1994) found lower SCC in the milk of cows with normal udder conformation $(\mathrm{r}=-0.16)$. In addition to udder attachment, udder placement can also affect SCC (Nash et al., 2000; Boichard and Krupp, 2001). Low SCC in cows together with a score of 4-5 points for placement of rear teats in both housing systems justifies selection for a smaller distance between udder teats. This is also confirmed by Rogers et al. (1991), who suggest that not only udder attachment but also teat placement can reduce SCC during selection for the milk yield of cows. As regards fore teats, the score for optimum placement ranges from 3 to 5 points and attempts at reducing the distance between the teats not only negatively affect milk parameters, but also make mechanical milking much more difficult. In studies by Krupp and Boichard (1999) and Boichard and Krupp (2001), the coefficients of correlation between teat length and SCC were low $(\mathrm{r}=0.08)$. Perhaps this is why the present study did not show a clear relationship between SCC in milk and fore teat placement, although SCC in cows with teats scoring 4-7 points tended to become stable. Studies carried out by Kozaniecki et al. (1985) showed, however, that the milk from $23.5 \%$ of the udder quarters examined with teat lengths of 6.6$8.0 \mathrm{~cm}$ contained somatic cells, compared with 11.4 and $14.8 \%$ of udder quarters with teat lengths of 5.6-6.5 and 3.0-4.5 cm, respectively.

\section{CONCLUSIONS}

The animal housing system has a highly significant effect on SCC level in milk. Genetic selection for improved udder conformation may fundamentally improve the quality of milk obtained and limit the effect of the housing system. Normal conformation of the udder and teat considerably reduces fluctuations in the level of SCC during a 305-day lactation. 


\section{REFERENCES}

Akers R.M., Thompson W., 1987. Effect of induced leukocyte migration on mammary cell morphology and milk component biosynthesis. J. Dairy Sci. 70, 1685-1695

Bogucki M., Sawa A., 2004. Factors of the microbiological quality of milk in view of some factors (in Polish). Zesz. nauk. Prz. hod. 72 (1), 177-183

Boichard D., Krupp R., 2001. Phenotypic and genetic relationships between somatic cell counts and clinical mastitis in French dairy Holstein cows. Interbull Bull., No.26, 66-71

Fetrow L., Anderson K., Sexton S., Butcher K., 1988. Herd composite somatic cell counts: average linear score and weighted average somatic cell count score and milk production. J. Dairy Sci. $71,257-260$

Jones G.M., Bailey T.L., 1998. Mastitis control in heifers and first lactation. Dairy Sci. Pub. 404281

Kozaniecki M., Grabowski R., Sciubisz A., Długołęcki L., 1985. Determining the relationship between udder conformation, milking capacity of cows and incidence of mastitis (in Polish). Zesz. probl. Post. Nauk rol., No. 300, 137-143

Krupp R., Boichard D., 1999. Genetic parameters for clinical mastitis, somatic cell score, production, udder type traits and milking ease in first lactation holsteins. J. Dairy Sci. 82, 2198-2204

Malinowski E., 2001. Somatic cells in milk. Med. wet. 57, 13-17

Monardes H.G., Cue R.I., Hayes J.F. 1990. Correlations between udder conformation traits and somatic cell count in Canadian Holstein cow. J. Dairy Sci. 73, 1337-1342

Nash D.L., Rogers G.W., Cooper J.B., Hargrove G.L., Keown J.F., Hansen L.B., 2000. Heritability of clinical mastitis incidence and relationships with sire transmitting abilities for somatic cell score, udder type traits, productive life and protein yield. J. Dairy Sci. 83, 2350-2360

Rajala-Schultz P.J., Grohn Y.T., McCulloch C.E., Guard C.L., 1999. Effects of clinical mastitis on milk yield in dairy cows. J. Dairy Sci. 82, 1213-1220

Regulations for Evaluation of Dairy Cattle Type and Conformation (in Polish), 1996. Central Animal Breeding Office, pp. 149-169

Rogers G.W., Hargrove G.L., Lawlor T.J., Ebersole J.L., 1991. Correlations among linear type traits and somatic cell counts. J. Dairy Sci. 73, 1087-1091

Sawa A., Piwczyński D., 2002. Somatic cells and yield and composition of milk from Black-andWhite x Holstein-Friesian cows (in Polish). Med. wet. 58, 636-640

Ward G.E., Schultz L.H., 1972. Relationship of somatic cells in quarter milk to type of bacteria and production. J. Dairy Sci. 73, 2538-2546

Zhang W.C., Dekkers J.C.M., Banos G., Burnside E.B., 1994. Adjustment factors and genetic evaluation for somatic cell score and relationship with other traits of Canadian Holsteins. J. Dairy Sci. 77, 659-665 